\title{
Cationic Amino Acid Transporter 2
}

National Cancer Institute

\section{Source}

National Cancer Institute. Cationic Amino Acid Transporter 2. NCI Thesaurus. Code C119688.

Cationic amino acid transporter $2(658 \mathrm{aa}, \sim 72 \mathrm{kDa})$ is encoded by the human SLC7A2 gene. This protein is involved in the transmembrane transport of cationic amino acids. 